\title{
Coastal Storm Monitoring in Virginia
}

Coastal communities in Virginia are prone to flooding, particularly during hurricanes, nor' easters, and other coastal low-pressure systems. These weather systems affect public safety, personal and public property, and valuable infrastructure, such as transportation, water and sewer, and electric-supply networks.

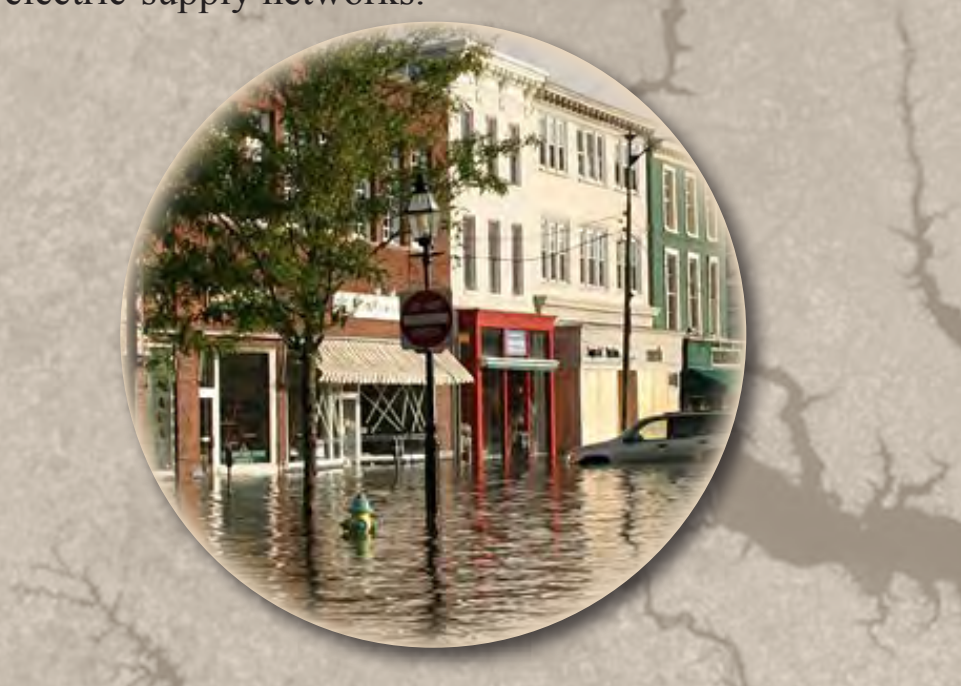

Local emergency managers, utility operators, and the public are tasked with making difficult decisions regarding evacuations, road closures, and post-storm recovery efforts as a result of coastal flooding. In coastal Virginia these decisions often are made on the basis of anecdotal knowledge from past events or predictions based on data from monitoring sites located far away from the affected

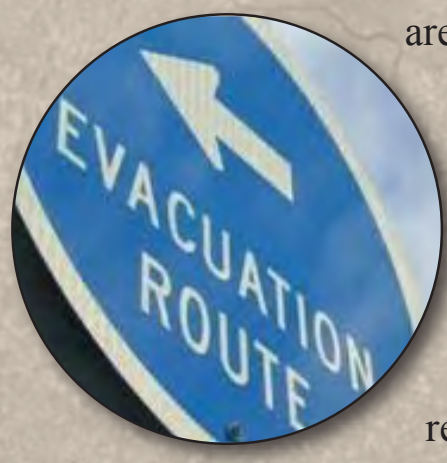

area that may not reflect local conditions.

Preventing flood hazards, such as hurricane-induced storm surge, from becoming human disasters requires an understanding of the relative risks that flooding poses to specific communities.
The risk to life and property can be very high if decisions about evacuations and road closures are made too late or not at all.

\section{What if there was more information available to help with these tough decisions?}

The U.S. Geological Survey (USGS) and National Oceanic and Atmospheric Administration (NOAA) currently operate a network of 15 continuous water-level monitors in coastal Virginia. The data from these monitors are publicly available in near-real time and are used to predict the timing and magnitude of flooding at those locations.

The current monitoring network primarily is located in Chesapeake Bay or far inland, and as a result many other areas do not have the benefit of water-level and flooding information near their location. Monitoring stations as near as possible to areas of concern provide the best information on current conditions and provide the best predictions for storm responses. Further, larger-scale regional predictions can be improved through addition of monitoring stations to the overall network, providing added benefit for communities throughout coastal

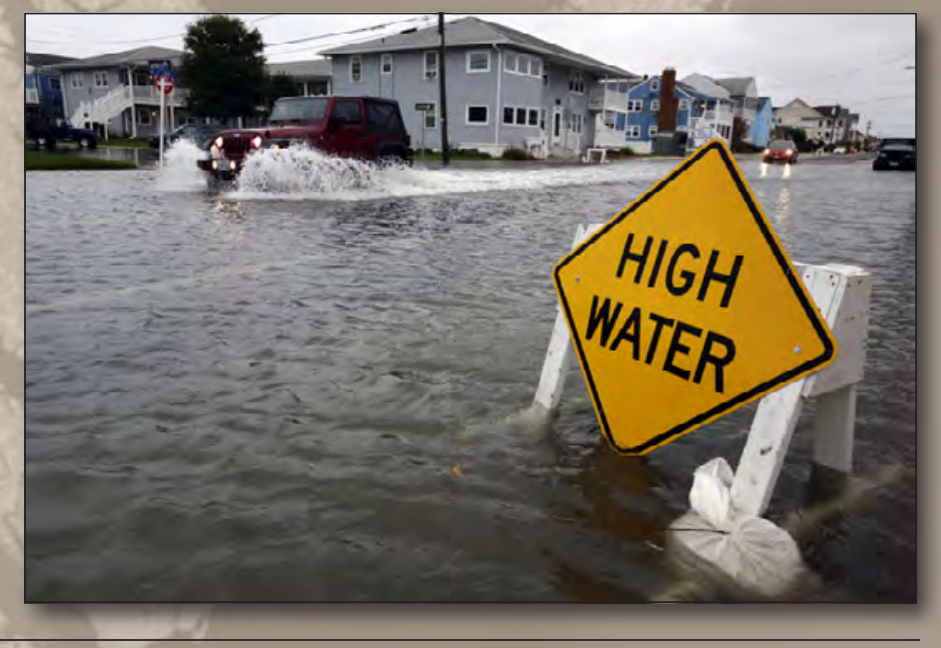


Virginia. In addition to monitoring water levels, these stations may also be equipped with rainfall and other meteorological sensors to assist in predictions and decision making during flood events. The USGS has expertise and resources to assist localities with more accurate and relevant information about local conditions. This assistance can be achieved through cooperative efforts to expand current monitoring activities.

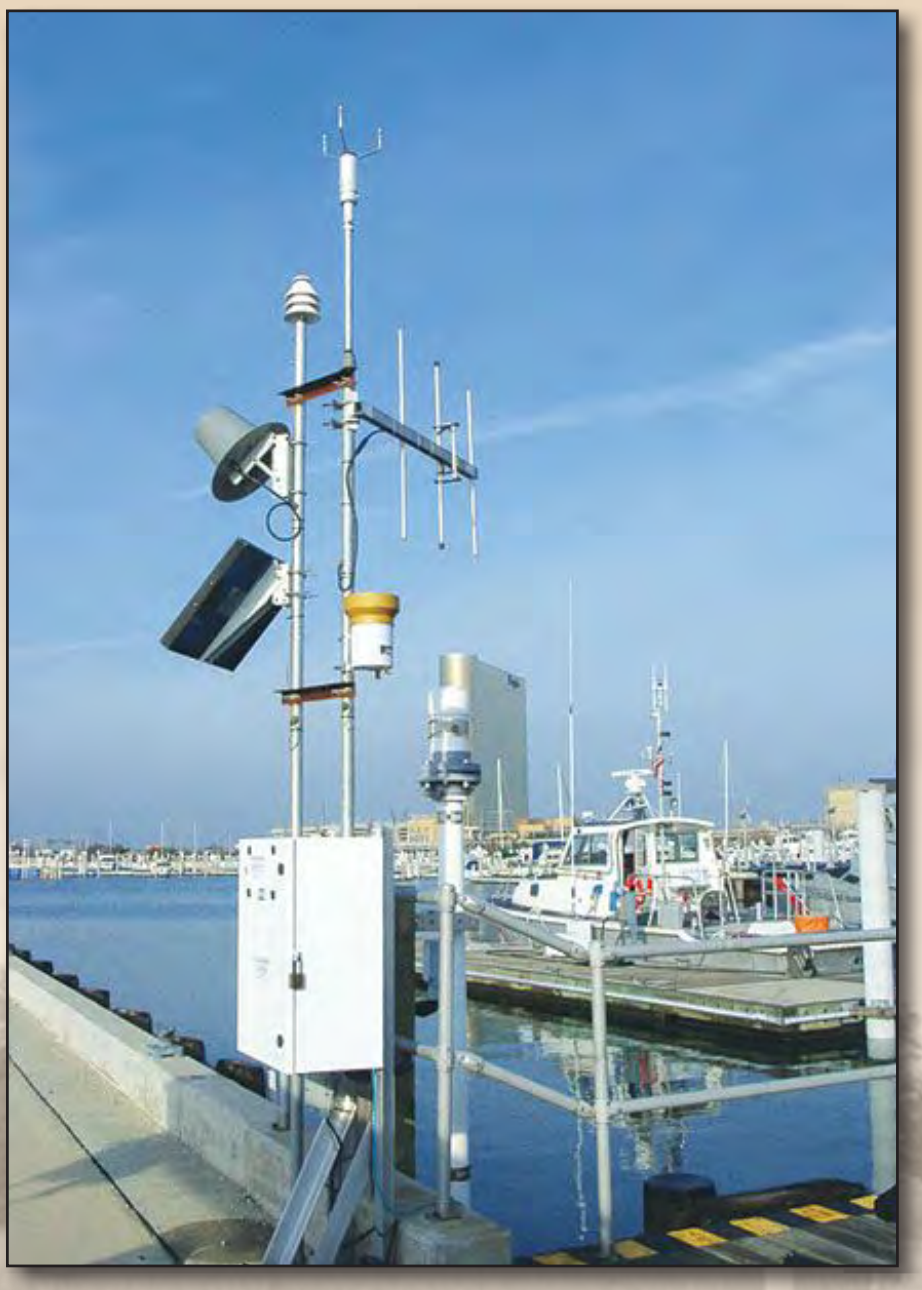

Helpful Links:

USGS Water Resources: http://www.usgs.gov/water/ USGS Virginia Water Science Center: http://va.water.usgs.gov/

USGS Flood Information: http://water.usgs.gov/floods/current/

USGS Water Data Discovery: http://water.usgs.gov/data/

National Weather Service Advanced Hydrologic Prediction Service: http://water.weather.gov/ahps/

\section{For more information, contact:}

Shaun Wicklein, USGS Virginia Water Science Center, smwickle@usgs.gov; 804-261-2605

Mark Bennett, USGS Virginia Water Science Center, mrbennet@usgs.gov; 804-261-2643

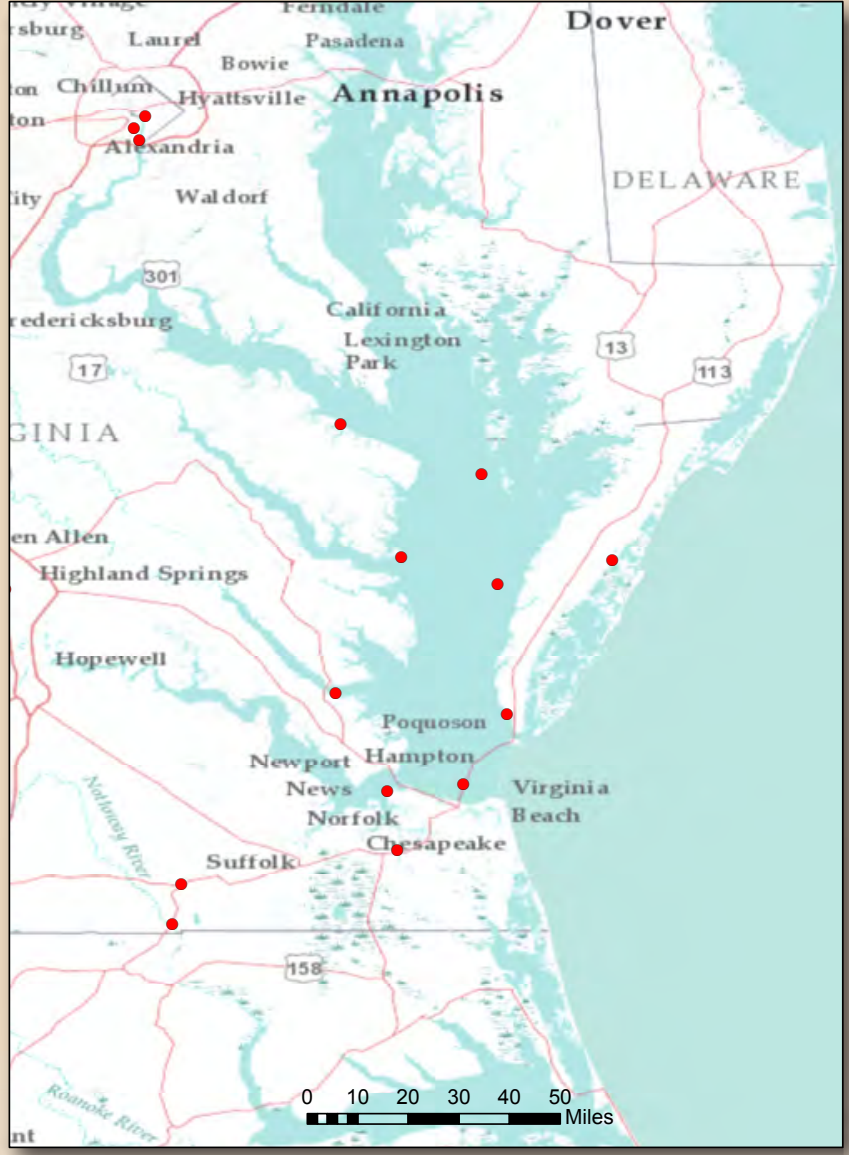

Map showing locations of active real-time USGS and NOAA water-level monitors in Virginia.

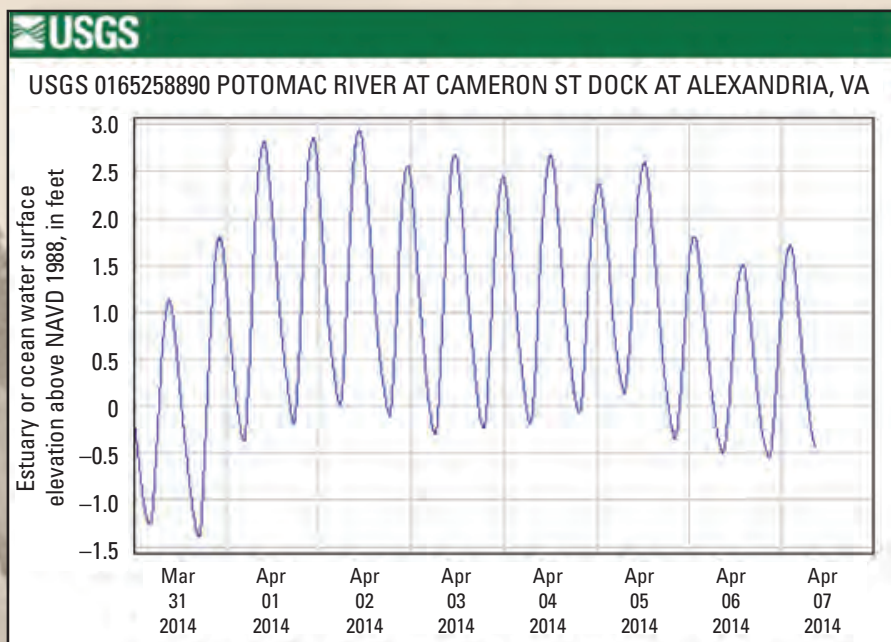

